\title{
Dietary isohumulones, the bitter components of beer, raise plasma HDL-cholesterol levels and reduce liver cholesterol and triacylglycerol contents similar to PPAR $\alpha$ activations in C57BL/6 mice
}

\author{
Yutaka Miura $^{1}$, Mayu Hosono ${ }^{1}$, Chiaki Oyamada ${ }^{1}$, Hideharu Odai $^{1}$, Shinichi Oikawa ${ }^{2}$ and Keiji Kondo ${ }^{1}$ \\ ${ }^{1}$ Central Laboratories for Key Technology, Kirin Brewery Co. Ltd, 1-13-5 Fukuura, Kanazawa-ku, Yokohamashi 236-0004, Japan \\ ${ }^{2}$ Department of Medicine, Nippon Medical School, Tokyo 113-8603, Japan
}

(Received 13 April 2004 - Revised 22 November 2004 - Accepted 22 November 2004)

\begin{abstract}
The effects of dietary isohumulones, the main components accounting for the bitter taste of beer, on lipid metabolism were examined. Young female C57BL/6N mice were fed diets containing isomerized hop extract (IHE), which consists mainly of isohumulones. Administration of IHE with an atherogenic (high-fat and high-cholesterol) diet for 2 weeks resulted in a significant increase in plasma HDL-cholesterol $(P<0 \cdot 01)$, along with a concomitant reduction in the atherosclerosis index, an increase in liver weight and a decrease in body weight gain in a dose-dependent manner. When animals received IHE with either a cholesterol or a basal diet for 1 week, significant decreases in the liver content of cholesterol $(P<0 \cdot 01)$ and triacylglycerol (cholesterol diet, $P<0.01)$ were observed. Quantitative analyses of hepatic mRNA levels revealed that IHE administration resulted in up-regulation of mRNA for acylCoA oxidase, acyl-CoA synthetase, hydroxymethylglutaryl-CoA synthetase, lipoprotein lipase and fatty acid transport protein, and down-regulation of mRNA for Apo CIII and Apo AI. Administration of purified isohumulones effectively resulted in the same changes as IHE. Administration of fenofibrate, an agonist for PPAR $\alpha$, with a cholesterol diet caused marked hepatomegaly, an increase in plasma HDL-cholesterol, a decrease in hepatic cholesterol content, and alterations in hepatic mRNA levels similar to those observed in mice given IHE. Taken together, these results suggest that the modulation of lipid metabolism observed in mice fed diets containing isohumulones is, at least in part, mediated by activation of PPAR $\alpha$.
\end{abstract}

Isohumulones: Beer: PPAR $\alpha$ : Lipid metabolism

Epidemiological studies have reported that moderate alcohol consumption is associated with decreased risk of CHD. The relationship between the amount of alcohol consumed and risk of CVD has been described as a J-shaped curve: the relative risk of mortality is lower for moderate drinkers than for non-drinkers, but then increases with higher levels of alcohol consumption (Doll et al. 1994; Fuchs et al. 1995; Gaziano et al. 2000). The protective effects of alcohol beverages on the vascular system can be attributed, in part, to the fact that ethanol can increase plasma levels of HDL and reduce thrombotic tendency by inhibiting platelet aggregation (Suh et al. 1992).

Non-alcohol components in alcohol beverages are also considered important for their cardioprotective effects. The high antioxidant activity of red wine resulting from the high content of polyphenols is one possible explanation for the 'French paradox' i.e. that some regions of France have lower mortality rates due to CVD than do North European countries, even though the populations are exposed to similar CVD risk factors (dietary fat intake and plasma cholesterol; Renaud \& de Lorgeril, 1992; Cripui \& Ringel, 1994). Hayek et al. (1997) reported that the progression of atherosclerosis in mice deficient in Apo $\mathrm{E}$ was reduced by the consumption of red wine or its polyphenols; this reduction was also associated with a decrease in the susceptibility of LDL to oxidation and aggregation. Furthermore, the consumption of red wine polyphenols in man has been reported to reduce the susceptibility of LDL to oxidation in vivo (Nigdikar et al. 1998).

Several studies have demonstrated that beer, as well as red wine, has beneficial effects in protecting against CHD (Hoffmeister et al. 1999; Brenner et al. 2001). It has been reported that moderate consumption of beer does not affect plasma levels of homocysteine, which promotes atherosclerosis and thrombosis, whereas the intake of red wine and spirits increases homocysteine levels (Van der Gaag et al. 2000). The high content of folate and vitamin $\mathrm{B}_{6}$ in beer is likely to be responsible for this effect. This observation is supported by epidemiological studies showing that there is a negative association between beer consumption and plasma homocysteine levels (Mayer et al. 2001; Mennen et al. 2003).

Beer is the only alcoholic beverage that contains hops, the female inflorescences of the hop plant (Humulus lupulus L.). Hops are used as a preservative and flavouring in beer. The bitter taste of beer is mainly attributed to isohumulones, which mostly comprise isohumulone, isocohumulone and isoadhumulone. Isohumulones are converted from humulones present in hops by isomerization

Abbreviations: 36B4, acidic ribosomal phosphoprotein P0; ACO, acyl-CoA oxidase; ACS, acyl-CoA synthetase; AI, atherosclerosis index; CYP7A1, cholesterol 7 $\alpha$-hydroxylase; FAS, fatty acid synthetase; FATP, fatty acid transport protein; HMGS, hydroxymethylglutaryl-CoA synthetase; HMGR, hydroxymethylglutaryl-CoA reductase; IHE, isomerized hop extract; LDLR, LDL receptor; LPL, lipoprotein lipase.

*Corresponding author: Dr Yutaka Miura, fax +81 45788 4042, email yu-miura@kirin.co.jp 
during the wort boiling step of the brewing process. Humulones have been reported to have various biological activities, such as inhibiting angiogenesis, inducing differentiation of myelogenous leukaemia cells and inhibiting bone resorption (Mizobuchi \& Sato, 1984, 1985; Miranda et al. 1993; Yasukawa et al. 1995; Tobe et al. 1997a,b; Honma et al. 1998; Yamamoto et al. 2000; Shimamura et al. 2001). Although the biological activities of humulones have been studied extensively, there are few studies concerning the activities of the isohumulones found in beer.

Recently, we found from reporter gene expression analyses that isohumulones can activate PPAR $\alpha$ and $\gamma$ (Yajima et al. 2004). PPAR $\gamma$ activators have been shown to improve insulin sensitivity and are commonly used to treat type 2 diabetes. Dietary administration of isohumulones to diabetic mice resulted in an improvement in insulin resistance, as did pioglitazone, a well-known PPAR $\gamma$ activator (Yajima et al. 2004). PPAR $\alpha$ is an important regulator of lipid metabolism and agonists for PPAR $\alpha$, which stimulate hepatic fatty acid oxidation, are used to treat hyperlipidaemia (Kersten et al. 2000). Therefore, it is reasonable to speculate that an intake of isohumulones from beer may modulate lipid metabolism.

The purpose of the present study was to evaluate the effect of isohumulones, the principal components accounting for the bitter taste of beer, on the metabolism of lipids in vivo in C57BL/6 mice.

\section{Materials and methods}

\section{Chemicals}

Two types of isomerized hop extract (IHE) containing isohumulones were used. One (Isomerized Kettle Extract; S. S. Steiner, Inc., New York, NY, USA) is a thick brown syrup and contains isohumulones (571 g/l), humulones (10 g/l), lupulones (165 g/l) and hop oil (65 g/l); it is termed IHE1 in this study. The other (ISOHOP CON2; English Hop Products Co. Ltd, Tonbridge, Kent, UK) is an aqueous solution containing isohumulones $(300 \mathrm{~g} / \mathrm{l})$, and is termed IHE2 in this study. Isohumulones are composed mainly of isohumulone [2-(3-methylbutanoyl)-5-(3-methyl-2-butenyl)-3,4-dihydroxy-4-(4-methyl-3-pentenoyl)-2-cyclopentenone], isocohumulone [2-(2-methylpropanoyl)-5(3-methyl-2-butenyl)-3,4-dihydroxy-4-(4-methyl-3-pentenoyl)-2cyclopentenone] and isoadohumulone [2-(2-methylbutanoyl)-5(3- methyl-2-butenyl)-3,4-dihydroxy-4-(4-methyl-3-pentenoyl)-2cyclopentenone]. Purified isohumulones were prepared from IHE2 by silica gel chromatography as follows. The IHE2 solution was neutralized to $\mathrm{pH} 7.8$ with $\mathrm{HCl}$ and passed over a silica gel column equilibrated with a solution of hexane-ethylacetate $(2: 1$, $\mathrm{v} / \mathrm{v})$. Isohumulones were eluted with the same solution and the eluates were evaporated under a stream of $\mathrm{N}_{2}$ gas. The isohumulones were diluted with an appropriate amount of ethanol and stored at $-70^{\circ} \mathrm{C}$ after being purged with $\mathrm{N}_{2}$ gas. All reagents and chemicals were extra-pure grade and commercially available.

\section{Animals}

Young female C57BL/6NCrj mice, 5 weeks old, were purchased from Charles River Japan Inc. (Tokyo, Japan). To accustom them to the experimental conditions, the mice were housed in animal rooms for at least $5 \mathrm{~d}$ before the experiments, with free access to food and water. Three or four mice were housed per cage, and food intake was measured on a per cage basis. The animals were treated in accordance with Kirin Pharmaceutical's ethical guidelines for animal care, handling and termination. These guidelines meet the generally accepted international criteria of humane treatment, i.e. sparing the animals needless pain and suffering and ensuring that the experiments conducted are of actual scientific benefit to mankind. At the end of the experiments, the mice were anaesthetized with diethyl ether at about 10.00 hours and killed by draining blood via the postcaval vein. The livers were removed immediately, frozen in liquid $\mathrm{N}_{2}$ and stored at $-80^{\circ} \mathrm{C}$.

\section{Diets and handling of samples}

The atherogenic (A) diet was prepared according to Nishina et al. $(1990,1993)$ and contained the following ingredients per $\mathrm{kg}$ : $150 \mathrm{~g}$ butter, $524.5 \mathrm{~g}$ sucrose, $200 \mathrm{~g}$ casein, $10 \mathrm{~g}$ corn oil, $50 \mathrm{~g}$ cellulose, $35 \mathrm{~g}$ AIN-93G mineral mixture (Reeves et al. 1993), $10 \mathrm{~g}$ AIN-93 vitamin mixture (Reeves et al. 1993), $2.5 \mathrm{~g}$ choline chloride, $3 \mathrm{~g}$ cystine, $10 \mathrm{~g}$ cholesterol and $5 \mathrm{~g}$ sodium cholate. AIN76-A diet (American Institute of Nutrition, 1977), which was purchased from Dyets Inc. (Bethlehem, PA, USA), was used as the basal (B) diet. The cholesterol (C) diet was prepared by adding cholesterol $(2 \mathrm{~g} / \mathrm{kg})$ to the basal diet. In all experiments, the dietary components were mixed, rolled into pellets with distilled water and stored at $-20^{\circ} \mathrm{C}$ until use to minimize the oxidation of isohumulones. Thawed feed was provided to animals daily.

\section{Experimental design}

In Expt 1, mice were fed the atherogenic diet for 1 week and then divided into five groups of nine animals each (except for the basal diet group, which contained six animals). Over the next 2 weeks, the groups were fed the atherogenic diet, the atherogenic diet supplemented with either two different concentrations of IHE1 (A + IHE1 (low), A + IHE1 (high)) or IHE2 (A + IHE2 (high)), or the basal diet. The A + IHE1 (low) diet contained $2 \mathrm{ml} \mathrm{IHE} 1 / \mathrm{kg}$ diet (equivalent to $1 \cdot 1 \mathrm{~g}$ isohumulones $/ \mathrm{kg}$ diet),

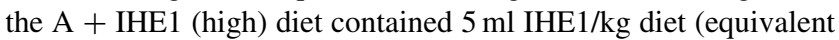
to $2.9 \mathrm{~g}$ isohumulones $/ \mathrm{kg}$ diet), and the A + IHE2 diet contained $10 \mathrm{ml} \mathrm{IHE} 2 / \mathrm{kg}$ diet (equivalent to $3 \mathrm{~g}$ isohumulones $/ \mathrm{kg}$ diet).

In Expt 2, mice were divided into four groups of five or six animals each. The groups were maintained for 1 week on the basal diet, the basal diet containing IHE2 (B + IHE2 diet; $10 \mathrm{ml}$ IHE $2 / \mathrm{kg}$ diet, equivalent to $3 \mathrm{~g}$ isohumulones $/ \mathrm{kg}$ diet), the cholesterol diet, or the cholesterol diet containing IHE2 (C + IHE2 diet; $10 \mathrm{ml} \mathrm{IHE} 2 / \mathrm{kg}$ diet, equivalent to $3 \mathrm{~g}$ isohumulones $/ \mathrm{kg}$ diet).

In Expt 3, mice were divided into three groups of eight or nine animals each. The groups were maintained for 2 weeks on the cholesterol diet without supplement, the cholesterol diet containing fenofibrate $(\mathrm{C}+\mathrm{F}$ diet; $0.5 \mathrm{~g}$ fenofibrate $/ \mathrm{kg}$ diet $)$, or the cholesterol diet containing IHE2 (C + IHE2 diet; $10 \mathrm{ml}$ IHE2/ $\mathrm{kg}$ diet, equivalent to $3 \mathrm{~g}$ isohumulones $/ \mathrm{kg}$ diet).

In Expt 4, mice were divided into three groups of seven or eight animals each. The groups were maintained for 1 week on the cholesterol diet, the cholesterol diet containing IHE2

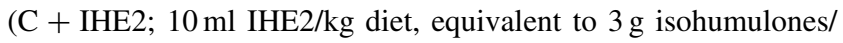
$\mathrm{kg}$ diet), or the cholesterol diet containing purified isohumulones (3 $\mathrm{g}$ isohumulones/kg diet).

All blood samples were taken from non-fasted mice except for Expt 1, where blood samples were removed from animals after an overnight fast. 


\section{Biochemical analyses}

Plasma lipids (total cholesterol, HDL-cholesterol and triacylglycerols) were determined using commercial kits (Cholesterol C-test, HDL cholesterol-test and Triglyceride G-test, respectively; Wako Pure Chemical, Osaka, Japan). To analyse the hepatic lipid content, approximately $0.2 \mathrm{~g}$ liver tissue was homogenized in saline and the lipids were extracted with chloroform-methanol mixture (2:1, v/v) as described by Carr et al. (1993). Liver cholesterol and triacylglycerols were measured with the kits described above. Gel filtration chromatography was performed using a Superose 6 HR 10/30 column (Amersham Pharmacia Biotech, Uppsala, Sweden) on $150 \mu \mathrm{l}$ pooled plasma (Ha \& Barter, 1985). The gel was allowed to equilibrate with $10 \mathrm{~mm}-\mathrm{PBS}$ containing EDTA $(0 \cdot 1 \mathrm{~g} / \mathrm{l})$ and sodium azide $(0 \cdot 1 \mathrm{~g} / \mathrm{l})$. Pooled plasma $(150 \mu \mathrm{l})$ was applied to the column and eluted with the same buffer at $4^{\circ} \mathrm{C}$ at a flow rate of $0.33 \mathrm{ml} / \mathrm{min}$. The eluate was collected in $0.5 \mathrm{ml}$ fractions. Cholesterol was measured in each fraction using the commercial enzymatic kit described above.

The atherosclerosis index (AI) was calculated as follows:

$\mathrm{AI}=($ total cholesterol $-\mathrm{HDL}$ cholesterol $) / \mathrm{HDL}$ cholesterol.

\section{Real-time quantitative PCR analysis of gene expression}

Light cycler analysis with SYBR green I fluorescence (Roche Diagnostics, Basel, Switzerland) was used to determine the relative mRNA levels of the genes involved in lipid metabolism. Oligonucleotide primers were designed using MacVector 6.5 (Teijin System Technology, Tokyo, Japan) for hydroxymethylglutaryl (HMG)-CoA reductase (HMGR; accession no. X07887 and X07888), HMG-CoA synthetase (HMGS; AK004865), LDL receptor (LDLR; NM_010700), acyl-CoA oxidase (ACO; NM_015729), acyl-CoA synthetase (ACS; U15977), fatty acid synthetase (FAS; AF127033), Apo AI (NM_009693), Apo CIII (NM_023114), lipoprotein lipase (LPL; NM_008509), cholesterol $7 \alpha$-hydroxylase (CYP7A1; L23754), fatty acid transport protein (FATP; AH006966) and acidic ribosomal phosphoprotein (36B4; X15267). The following PCR reaction primers were used: for HMGR, $5^{\prime}$-TTG GCC TCC ATT GAG ATC CG-3' (5 $^{\prime}$ primer) and $5^{\prime}$-GAT CTT GTT GTT GCC GGT GAA C-3' $\left(3^{\prime}\right.$ primer); for HMGCS, 5'-CCT TCA GGG GTC TAA AGC TGG AAG- $3^{\prime}\left(5^{\prime}\right.$ primer $)$ and $5^{\prime}$-CAG CCA ATT CTT GGG CAG AGT G-3' (3' primer); for LDLR, 5'-CAT CAA GGA GTG CAA GAC CAA CG- $3^{\prime}\left(5^{\prime}\right.$ primer $)$ and $5^{\prime}$-CAC TTG TAG CTG CCT TCC AGG TTC- $3^{\prime}$ ( $3^{\prime}$ primer); for ACO, $5^{\prime}-$ ATC TAT GAC CAG GTT CAG TCG GGG- $3^{\prime}\left(5^{\prime}\right.$ primer) and $5^{\prime}$-CCA CGC CAC TTC CTT GCT CTT C-3' (3' primer); for ACS, 5'-GGA ACT ACA GGC AAC CCC AAA G-3' $3^{\prime}\left(5^{\prime}\right.$ primer) and $5^{\prime}$-CTT GAG GTC GTC CAT AAG CAG C-3' $\left(3^{\prime}\right.$ primer); for FAS, $5^{\prime}$-TCG CTC ATG GGT GTG GAA GTT C$3^{\prime}\left(5^{\prime}\right.$ primer) and $5^{\prime}$-TGC TCA GGT TCA GTT GGT TCT GC-3' ( $3^{\prime}$ primer); for Apo AI, 5'-TGT ATG TGG ATG CGG TCA AAG AC- $3^{\prime}\left(5^{\prime}\right.$ primer) and $5^{\prime}$-TCA TCT CCT GTC TCA CCC AAT CTG-3' $3^{\prime} 3^{\prime}$ primer); for Apo CIII, 5'-AGG GCT ACA TGG AAC AAG CCT C- $3^{\prime}\left(5^{\prime}\right.$ primer) and $5^{\prime}$-CGA CTC AAT AGC TGG AGT TGG TTG-3' ( $3^{\prime}$ primer); for LPL, $5^{\prime}$-GTT TGG CTC CAG AGT TTG ACC G-3' (5' primer) and $5^{\prime}$-CAT ACA TTC CCG TTA CCG TCC ATC-3' (3' primer); for CYP7A1, 5'-ACG GGT TGA TTC CAT ACC TGG G-3'
(5' primer) and $5^{\prime}$-TGT GTC CAA ATG CCT TCG CAG- $3^{\prime}\left(3^{\prime}\right.$ primer); for FATP, $5^{\prime}$-TGC TAG TGA TGG ACG AGC TGG$3^{\prime}\left(5^{\prime}\right.$ primer) and $5^{\prime}$-TCC TGG TAC ATT GAG TTA GGG TCC- $3^{\prime}$ ( $3^{\prime}$ primer); and for 36B4, 5'-CCA AGC AGA TGC AGC AGA TCC- $3^{\prime}\left(5^{\prime}\right.$ primer) and $5^{\prime}$-CAG CAG CTG GCA CCT TAT TGG-3' (3' primer).

Total RNA was isolated from the liver samples by using ISOGEN (Nippon Gene, Toyama, Japan) according to the manufacturer's instructions, and $2.5 \mu \mathrm{g}$ of total RNA was used for reverse transcription with oligo $(\mathrm{dT})$ primers and the ThermoScript $^{\mathrm{TM}}$ RT-PCR system (Gibco BRL, New York, NY, USA). Aliquots of $20 \mu \mathrm{l}$ were used for light cycler analysis under the conditions suggested by the supplier. Data were analysed using Light Cycler Software (Roche Molecular Biochemicals, Mannheim, Germany). Relative mRNA expression levels of the target genes were normalized to those of $36 \mathrm{~B} 4$.

\section{Statistical analysis}

Results are expressed as mean values and standard deviations of five to nine mice per group. Statistical analysis of the differences among values was carried out by one-way ANOVA in Expts 1, 3 and 4. When ANOVA revealed a statistical significance, Fisher's protected least significant difference test was performed. In Expt 2 , the significance of values was analysed by two-way ANOVA. When the interaction was significant (cholesterol $X$ isohumulones), Student's $t$ test was performed. Differences were considered significant at $P<0.05$. All statistical analyses were performed using StatView (SAS Institute Inc., Cary, NC, USA).

\section{Results}

Effects of isomerized hop extracts on body weight and plasma cholesterol and triacylglycerols in mice fed the atherogenic diet (Expt 1)

Two different IHE, IHE1 and IHE2, were used in this experiment. IHE1 contains lupulones and humulones in addition to isohumulones, whereas IHE2 contains isohumulones only (see p. 2). Body weight gain during the 2-week experiment and final body weight of the groups fed IHE with the atherogenic diet (containing high concentrations of cholesterol and fat) were significantly lower $(P<0.01)$ than those of the control group fed the atherogenic diet without hop extracts (Table 1). There was no noticeable decrease in total food intake in the groups given IHE. Administration of the atherogenic diet significantly increased $(P<0 \cdot 01)$ liver weight by $40 \%$ compared with the group fed the basal diet. Supplementation of the atherogenic diet with high doses of IHE1 and IHE2 further increased liver weight (by $12 \%$ in each group).

There were no detectable differences in plasma levels of the hepatic enzymes glutamic oxaloacetic transaminase and glutamic pyruvic transaminase among the experimental groups (data not shown). Administration of the atherogenic diet decreased plasma HDLcholesterol significantly and therefore increased the AI $(P<0 \cdot 01)$, as compared with the group fed the basal diet. Administration of IHE coupled with the atherogenic diet cancelled out this decrease in HDL-cholesterol at a low dose (A + IHE1 (low), $34 \%$ increase) and significantly raised plasma HDL-cholesterol at a high dose (A + IHE1 (high) and A + IHE2 (high), $90 \%$ and $70 \%$ increase, respectively, $P<0.01$; Table 1 ). The increase in plasma total cholesterol levels in the groups receiving diets supplemented with IHE was 
Table 1. Body weight, energy intake, organ weight and plasma lipid content in mice fed the atherogenic diet, the atherogenic diet supplemented with isomerized hop extract (IHE) and the basal diet for 2 weeks $\dagger$

(Mean values with standard deviations for nine mice per group in $\mathrm{A}, \mathrm{A}+\mathrm{IHE} 1$ (low), $\mathrm{A}+\mathrm{IHE}$ ( high) and $\mathrm{A}+\mathrm{IHE} 2$ (high) diet groups and for five mice in the B diet group)

\begin{tabular}{|c|c|c|c|c|c|c|c|c|c|c|}
\hline & \multicolumn{2}{|c|}{ A } & \multicolumn{2}{|c|}{$\mathrm{A}+\mathrm{IHE} 1$ (low) } & \multicolumn{2}{|c|}{ A + IHE1 (high) } & \multicolumn{2}{|c|}{ A + IHE2 (high) } & \multicolumn{2}{|c|}{$B$} \\
\hline & Mean & SD & Mean & SD & Mean & SD & Mean & SD & Mean & SD \\
\hline Body weight gain (g) & $1 \cdot 75$ & 0.75 & $0.58^{\star \star}$ & 0.79 & $0.43^{* *}$ & 0.65 & $0.61^{\star *}$ & 0.74 & 1.42 & 0.68 \\
\hline Final body weight $(\mathrm{g})$ & $17 \cdot 98$ & $1 \cdot 16$ & $16 \cdot 70^{\star *}$ & 0.88 & $16 \cdot 44^{\star \star}$ & 0.75 & $17 \cdot 07^{\star \star}$ & 0.86 & $17 \cdot 20$ & 0.49 \\
\hline Food intake (kJ/2 weeks per mouse) & $43 \cdot 1$ & & $41 \cdot 0$ & & $43 \cdot 1$ & & $40 \cdot 5$ & & $43 \cdot 9$ & \\
\hline \multicolumn{11}{|l|}{ Tissue weight (g/body kg) } \\
\hline Liver & $56 \cdot 47$ & 4.65 & $56 \cdot 34$ & $4 \cdot 28$ & $63 \cdot 42^{\star *}$ & 6.00 & $63 \cdot 38^{\star *}$ & 4.69 & $40 \cdot 31^{\star *}$ & $3 \cdot 17$ \\
\hline Kidney & 11.47 & 0.89 & $11 \cdot 32$ & 0.59 & $10 \cdot 96$ & 0.62 & $10 \cdot 90$ & 0.77 & $12 \cdot 74^{\star \star}$ & 0.55 \\
\hline Plasma total cholesterol (mmol/l) & $2 \cdot 42$ & 0.39 & $2 \cdot 83^{\star}$ & 0.49 & $3.48^{\star \star}$ & 0.48 & $3 \cdot 34^{\star \star}$ & 0.38 & 2.39 & 0.25 \\
\hline Plasma HDL-cholesterol (mmol/l) & 0.96 & $0 \cdot 16$ & $1 \cdot 29^{\star}$ & 0.25 & $1 \cdot 83^{\star *}$ & 0.31 & $1 \cdot 63^{\star \star}$ & $0 \cdot 16$ & $1 \cdot 32^{\star \star}$ & $0 \cdot 14$ \\
\hline $\mathrm{Al}$ & 1.52 & 0.20 & $1 \cdot 26$ & 0.59 & $0.94^{* *}$ & 0.42 & $1.06^{\star \star}$ & 0.31 & $0.81^{\star \star}$ & $0 \cdot 10$ \\
\hline Plasma TAG (mmol/l) & 0.49 & 0.07 & 0.44 & $0 \cdot 12$ & 0.46 & 0.14 & $0.35^{\star}$ & 0.08 & $0.82^{\star \star}$ & $0 \cdot 15$ \\
\hline
\end{tabular}

A, atherogenic diet group; A + IHE1 (low), A diet supplemented with IHE1 (2 ml/kg, equivalent to $1.1 \mathrm{~g}$ isohumulones/kg) group; A IHE1 (high), A diet supplemented with IHE1 $(5 \mathrm{ml} / \mathrm{kg}$, equivalent to $2.9 \mathrm{~g}$ isohumulones $/ \mathrm{kg}$ ) group; A + IHE2 (high), A diet supplemented with IHE2 $(10 \mathrm{ml} / \mathrm{kg}$, equivalent to $3 \mathrm{~g}$ isohumulones $/ \mathrm{kg}$ ) group; B, basal diet group; Al, atherogenic index; TAG, triacylglycerols.

Mean values were significantly different from those of the A diet group: ${ }^{*} P<0.05,{ }^{\star *} P<0.01$

tFor details of diets and procedures, see p. 560 .

attributed to the increase in HDL-cholesterol. Therefore, the AI values declined in a dose-dependent manner in the groups fed IHE.

Pooled plasma from mice fed the atherogenic diet plus IHE2 (A + IHE2 (high) diet) was fractionated by gel filtration chromatography and the distribution of cholesterol was measured (Fig. 1). The profile suggested that the number of HDL particles in the plasma of IHE-fed mice increased, whereas the number of LDL particles did not change, compared with mice fed the atherogenic diet. This observation is consistent with our result indicating that there was a specific increase in the level of plasma HDL-cholesterol in the groups fed IHE diets (Table 1).

Plasma triacylglycerol levels tended to decrease in the groups given IHE, and this decrease was significant in the group fed the atherogenic diet containing a high dose of IHE2 (A + IHE2 (high), $29 \%$ reduction, $P<0.05$; Table 1 ). Taken together, these results indicated that the two IHE, IHE1 and IHE2, were equally

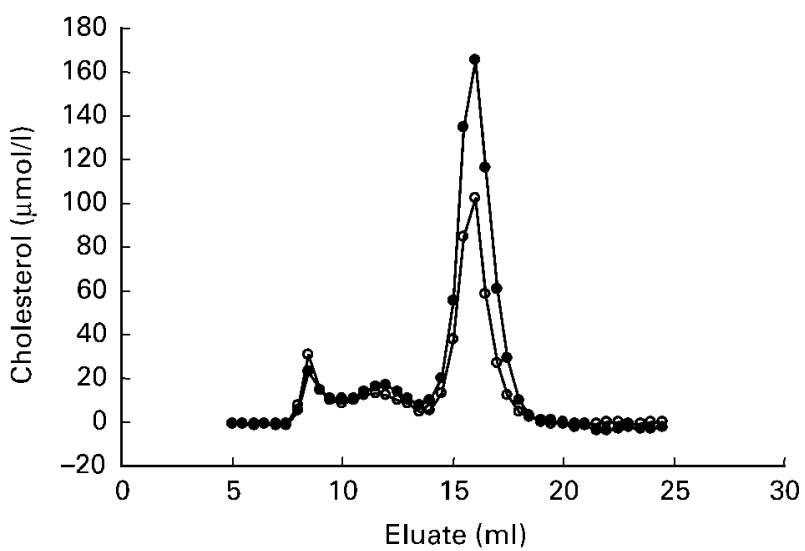

Fig. 1. Distribution of cholesterol in pooled plasma from mice fed the atherogenic diet $(A, O)$ and the atherogenic diet supplemented with isomerized hop extract ( $\mathrm{A}+\mathrm{IHE} 2$ (high), $\bullet$ ). Animals were given either the atherogenic diet or the A + IHE2 (high) diet for 2 weeks. In each group, plasma samples of $150 \mu \mathrm{l}$ were taken from animals whose HDL-cholesterol levels were similar to the mean values of each group. The samples were analysed by gel filtration chromatography using a Superose 6 HR 10/30 column and the eluted fractions were assessed for cholesterol concentration. effective in changing the parameters investigated (Table 1). Therefore, IHE2, in which the major constituents are isohumulones, was used in the subsequent experiments.

Effect of dietary isomerized hop extract on lipids in the liver (Expt 2)

We examined the effect of IHE on lipid metabolism by using two diets, the basal diet and the cholesterol diet. A significant suppression in body weight gain was observed in the group fed IHE with the cholesterol diet $(\mathrm{C}+\mathrm{IHE} 2,76 \%$ decrease compared with the cholesterol diet, $P<0 \cdot 05)$, although no significant differences in food intake or final body weight were observed among the four groups (Table 2). Administration of IHE caused an increase in liver weight, regardless of the presence of cholesterol, but this increase was significant only when IHE was given with the basal diet (B + IHE2, $28 \%$ increase for the basal diet, $P<0 \cdot 01$; Table 2). Dietary IHE tended to increase the level of plasma HDL-cholesterol and thus decrease the AI, although the differences were not so marked as those detected in the groups fed the atherogenic diets. Liver contents of cholesterol and triacylglycerols in mice fed the cholesterol diet plus IHE (C + IHE2) were markedly reduced compared with those found in mice fed the cholesterol diet (38\% and $37 \%$ decrease, respectively, $P<0.01$; Table 2$)$. A reduction in liver cholesterol and triacylglycerol contents was also observed in mice fed IHE with the basal diet (B + IHE2, 33\% $(P<0.01)$ and $12 \%$ decrease, respectively; Table 2$)$.

Effect of dietary isomerized hop extract on hepatic mRNA levels (Expt 2)

We performed quantitative, real-time, RT-PCR analyses to measure mRNA levels in the livers of mice from four dietary groups (Fig. 2). mRNA levels, which were first normalized to levels of 36B4 mRNA in the same samples as an internal control, were determined relative to the mRNA levels in the group fed the cholesterol diet. Administration of IHE caused an approximately twofold increase in the levels of mRNA for enzymes involved 
Table 2. Body weight, energy intake, liver weight, plasma lipid content and hepatic lipid content in mice fed the cholesterol diet, the basal diet, and the cholesterol and basal diets supplemented with isomerized hop extract (IHE) for 1 week $\dagger$

(Mean values with standard deviations for five or six mice per group)

\begin{tabular}{|c|c|c|c|c|c|c|c|c|c|c|c|}
\hline & \multicolumn{2}{|c|}{ C } & \multicolumn{2}{|c|}{$\mathrm{C}+\mathrm{IHE} 2$} & \multicolumn{2}{|c|}{ B } & \multicolumn{2}{|c|}{$\mathrm{B}+\mathrm{IHE} 2$} & \multicolumn{3}{|c|}{ ANOVA } \\
\hline & Mean & SD & Mean & SD & Mean & SD & Mean & SD & Cholesterol & Isohumulone & Interaction \\
\hline Body weight gain (g) & 1.07 & 0.41 & $0.25^{\star}$ & 0.42 & 0.68 & 0.54 & 0.82 & 0.38 & NS & NS & 0.05 \\
\hline Final body weight (g) & $17 \cdot 09$ & 0.99 & $16 \cdot 33$ & 0.40 & $16 \cdot 55$ & 0.54 & $16 \cdot 60$ & 0.63 & NS & NS & NS \\
\hline $\begin{array}{l}\text { Food intake (kJ/week } \\
\text { per mouse) }\end{array}$ & $54 \cdot 0$ & & $51 \cdot 1$ & & $54 \cdot 4$ & & 61.5 & & & & \\
\hline Liver weight (g/body kg) & 61.92 & $4 \cdot 87$ & $67 \cdot 77$ & 5.47 & $52 \cdot 2$ & $1 \cdot 28$ & $66 \cdot 61^{\star \star *}$ & $3 \cdot 66$ & 0.01 & 0.01 & 0.05 \\
\hline $\begin{array}{l}\text { Plasma HDL-cholesterol } \\
(\mathrm{mmol} / \mathrm{l})\end{array}$ & 0.98 & $0 \cdot 15$ & $1 \cdot 12$ & 0.05 & $1 \cdot 28$ & 0.09 & $1 \cdot 33$ & $0 \cdot 13$ & 0.01 & NS & NS \\
\hline $\mathrm{Al}$ & 0.98 & 0.26 & 0.86 & 0.15 & 0.73 & $0 \cdot 12$ & 0.59 & $0 \cdot 11$ & 0.01 & NS & NS \\
\hline Plasma TAG (mmol/l) & $0 \cdot 81$ & $0 \cdot 24$ & 0.95 & 0.19 & 0.84 & 0.26 & 0.71 & 0.18 & NS & NS & NS \\
\hline \multicolumn{12}{|l|}{ Liver lipid ( $\mu \mathrm{mol} / \mathrm{g}$ liver) } \\
\hline Cholesterol & $30 \cdot 07$ & $5 \cdot 40$ & $18 \cdot 50^{\star \star}$ & 3.60 & $8 \cdot 48$ & 1.54 & $5 \cdot 65^{\star \star \star}$ & 0.77 & 0.01 & 0.01 & 0.01 \\
\hline TAG & 39.66 & $8 \cdot 14$ & $24 \cdot 97^{\star \star}$ & $3 \cdot 16$ & 24.97 & 3.96 & 21.92 & 5.76 & 0.01 & 0.01 & 0.05 \\
\hline
\end{tabular}

C, cholesterol diet group; C + IHE2, C diet supplemented with IHE2 (10 ml/kg, equivalent to $3 \mathrm{~g}$ isohumulones $/ \mathrm{kg})$ group; B, basal diet group; B + IHE2, B diet supplemented with IHE2 (10 ml/kg, equivalent to $3 \mathrm{~g}$ isohumulones $/ \mathrm{kg}$ ) group; Al, atherogenic index; TAG, triacylglycerols.

Mean values were significantly different from those of the $C$ diet group: ${ }^{*} P<0.05,{ }^{* \star} P<0.01$.

Mean values were significantly different from those of the $B$ diet group: ${ }^{\star \star \star} P<0.01$

†For details of diets and procedures, see p. 560 .

in fatty acid oxidation, ACO, ACS, LPL and FATP, regardless of the presence of cholesterol. Administration of IHE also caused a slight but significant increase $(P<0.05)$ in the levels of mRNA for HMGS and LDLR in the basal diet context. By contrast, mRNA levels for apolipoproteins Apo AI and Apo CIII were decreased in the mice given IHE. No significant fluctuation was observed in levels of mRNA for the cholesterologenic enzyme HMGR, the

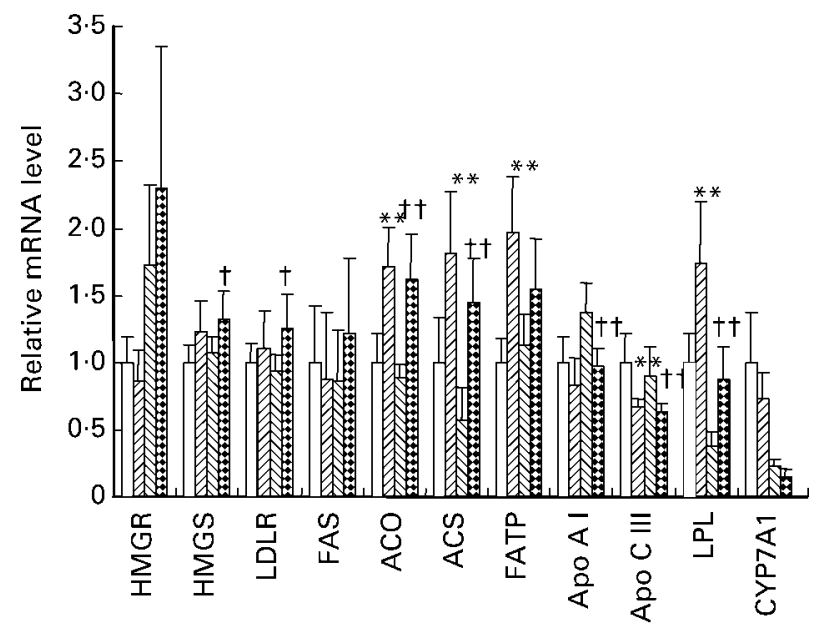

Fig. 2. Quantitative analysis of mRNA in the liver of mice fed the cholesterol diet $(C, \square)$, the cholesterol diet supplemented with isomerized hop extract $(\mathrm{C}+\mathrm{IHE} 2, \mathbb{2})$, the basal diet $(\mathrm{B}, \mathbb{\mathbb { Q }})$ or the basal diet supplemented with IHE2 (B + IHE2, for 1 week. For each gene, the mRNA level is shown relative to its level in the $C$ group (set as 1.0). Values are means with standard deviations represented by vertical bars for five or six mice per group ( $n$ 6 except for the B group, where $n 5$ ). Mean values were significantly different from those of the $C$ group: ${ }^{\star} P<0.05$; ${ }^{\star \star} P<0.01$. Mean values were significantly different from those of the $B$ group: $\dagger P<0.05$; $\dagger \uparrow P<0.01$. ACO, acylCoA oxidase; ACS, acyl-CoA synthetase; CYP7A1, cholesterol $7 \alpha$-hydroxylase; FAS, fatty acid synthetase; FATP, fatty acid transport protein; HMGR, hydroxymethylglutaryl (HMG)-CoA reductase; HMGS, HMG-CoA synthetase; LDLR, LDL receptor; LPL, lipoprotein lipase. lipogenic enzyme FAS, and the cholesterol excretion enzyme CYP7A1.

Effects of dietary isomerized hop extract and fenofibrate on liver lipid and gene expression (Expt 3)

We compared the effects of IHE on liver lipid content and hepatic mRNA levels with those of fenofibrate, a well-known PPAR $\alpha$ agonist that is used for the medical treatment of hyperlipidaemia. Administration of fenofibrate with the cholesterol diet for 2 weeks exaggerated the changes that had been observed in IHE-fed mice, i.e. marked hepatomegaly (64\% increase in the weight), a significant decrease in hepatic cholesterol content (53\%), a significant increase in plasma HDL-cholesterol (69\%) and a significant decrease in plasma triacylglycerols $(56 \%)$ were observed in the group given fenofibrate (all $P<0.01$, Table 3). IHE increased liver weight by $19 \%$ and decreased hepatic cholesterol by $32 \%$ $(P<0 \cdot 01)$. Administration of IHE also caused a slight increase in HDL-cholesterol and a decrease in plasma triacylglycerols, although the changes were not significant. Notably, IHE caused a greater reduction in hepatic triacylglycerol content than did fenofibrate (33\% and $7 \%$ reductions, respectively).

The effects of fenofibrate and IHE were assessed by determining the levels of mRNA that are potentially regulated by PPAR $\alpha$ in mice (Fig. 3). Both fenofibrate $(P<0.01)$ and IHE $(P<0.05)$ significantly increased the hepatic levels of mRNA for ACO and LPL, but fenofibrate induced ACO and LPL mRNA levels to a greater extent than did IHE.

Comparison of the effects of dietary isomerized hop extract and isohumulones (Expt 4)

Isohumulones were purified from IHE2 and given to the mice for 1 week. The administration of purified isohumulones $(3 \mathrm{~g} / \mathrm{kg}$ cholesterol diet) had almost the same effect as administration of IHE2 (10 $\mathrm{ml} / \mathrm{kg}$ cholesterol diet, equivalent to $3 \mathrm{~g}$ isohumulones/ 
Table 3. Body weight, energy intake, liver weight, plasma lipid content and hepatic lipid content in mice fed the cholesterol diet, and the cholesterol diets supplemented with isomerized hop extract (IHE) and fenofibrate for 2 weeks $†$

(Mean values with standard deviations for eight or nine mice per group)

\begin{tabular}{|c|c|c|c|c|c|c|}
\hline & \multicolumn{2}{|c|}{$\mathrm{C}$} & \multicolumn{2}{|c|}{$\mathrm{C}+\mathrm{IHE} 2$} & \multicolumn{2}{|c|}{$C+F$} \\
\hline & Mean & SD & Mean & SD & Mean & SD \\
\hline Body weight gain (g) & 1.47 & 0.22 & $1 \cdot 12$ & 1.00 & 2.52 & 1.05 \\
\hline Final body weight $(\mathrm{g})$ & 17.09 & 0.61 & $16 \cdot 52$ & 0.91 & $17 \cdot 48$ & $1 \cdot 23$ \\
\hline Food intake (kJ/2 weeks per mouse) & 44.4 & & 41.0 & & 43.5 & \\
\hline Liver weight (g/body kg) & 55.48 & $3 \cdot 12$ & $66 \cdot 27^{\star \star}$ & 8.47 & $91 \cdot 08^{\star \star}$ & $9 \cdot 26$ \\
\hline Plasma total cholesterol (mmol/l) & $2 \cdot 22$ & 0.24 & $2 \cdot 27$ & 0.27 & $3.43^{\star *}$ & 0.58 \\
\hline Plasma HDL-cholesterol (mmol/l) & 1.37 & 0.22 & 1.44 & 0.27 & $2 \cdot 31^{\star *}$ & 0.34 \\
\hline Al & 0.63 & 0.11 & 0.60 & 0.13 & $0.48^{*}$ & 0.12 \\
\hline Plasma TAG (mmol/l) & 1.07 & 0.37 & 0.99 & 0.31 & $0.47^{\star \star}$ & 0.05 \\
\hline \multicolumn{7}{|l|}{ Liver lipid ( $\mu \mathrm{mol} / \mathrm{g}$ liver) } \\
\hline Cholesterol & $41 \cdot 12$ & $2 \cdot 83$ & $28 \cdot 01^{\star *}$ & 3.86 & $19 \cdot 28^{\star \star}$ & 1.54 \\
\hline TAG & $57 \cdot 18$ & 8.93 & $38 \cdot 31^{* *}$ & 11.41 & 53.56 & $12 \cdot 66$ \\
\hline
\end{tabular}

C, cholesterol diet group; C + IHE2, C diet supplemented with IHE2 $(10 \mathrm{ml} / \mathrm{kg}$, equivalent to $3 \mathrm{~g}$ isohumulones $/ \mathrm{kg})$ group; $\mathrm{C}+\mathrm{F}, \mathrm{C}$ diet supplemented with fenofibrate $(5 \mathrm{~g} / \mathrm{kg})$ group; Al, atherogenic index; TAG, triacylglycerols.

Mean values were significantly different from those of the $C$ diet group: ${ }^{*} P<0.05,{ }^{\star \star} P<0.01$.

$\dagger$ For details of diets and procedures, see p. 560.

$\mathrm{kg}$ cholesterol diet) on liver lipid content and mRNA levels (Table 4 and Fig. 4). No notable difference was observed in the extent of the increase in ACO and LPL mRNA levels or in the extent of the reduction in hepatic cholesterol and triacylglycerol content between the two groups (Table 4 and Fig. 4). From these results, it seems reasonable to conclude that isohumulones are responsible for the hypolipidaemic effects of IHE.

\section{Discussion}

This study was conducted to examine whether isohumulones, the main components accounting for the bitter taste of beer, affect lipid metabolism in vivo by using an animal model. Administration of the atherogenic diet containing IHE, in which isohumulones aref major ingredients, led to a significant increase in plasma HDL-cholesterol, coupled with a concomitant reduction in the AI,

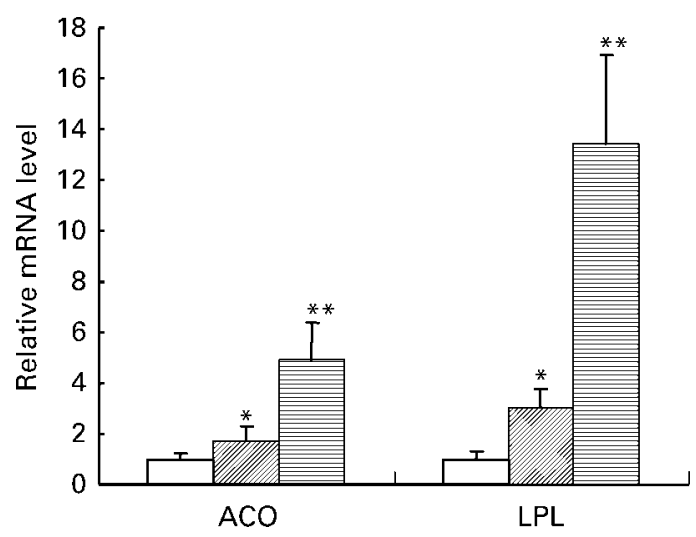

Fig. 3. Quantitative analysis of mRNA in the liver of mice fed the cholesterol diet $(C, \square)$, the cholesterol diet supplemented with isomerized hop extract $(\mathrm{C}+\mathrm{IHE} 2, \mathbb{2})$ and the cholesterol diet supplemented with fenofibrate $(\mathrm{C}+\mathrm{F}$, 目) for 2 weeks. For each gene, the mRNA level is shown relative to its level in the $\mathrm{C}$ group (set as 1). Values are means with standard deviations represented by vertical bars for five mice per group. Mean values were significantly different from those of the $C$ group: ${ }^{\star} P<0.05 ;{ }^{\star \star} P<0.01$. ACO, acylCoA oxidase; LPL, lipoprotein lipase. in a dose-dependent manner in mice (Table 1). A specific increment in the HDL-cholesterol fraction in plasma was confirmed by gel filtration chromatography (Fig. 1). It should be noted that the significant increase in plasma HDL-cholesterol by IHE was observed on the atherogenic diet (Table 1), while the increases in plasma HDL-cholesterol by IHE on the basal and cholesterol diets were not significant (Tables 2 and 3). A significant decrease in the hepatic triacylglycerol and cholesterol content in mice given cholesterol and basal diets supplemented with IHE was also observed (Tables 2 and 3).

Quantitative analyses of the mRNA in liver revealed that administration of IHE with either the cholesterol or the basal diet caused a significant increase in, or tended to increase, the levels of ACO, ACS, FATP, LPL and HMGS mRNA, and also caused a significant decrease in, or tended to decrease, the levels of Apo AI and Apo CIII mRNA (Fig. 2). The enzymes encoded by ACS, FATP and ACO mRNA are involved in cellular fatty acids uptake, first step prior to transport of fatty acids into the mitochondria, and the peroxisomal $\beta$-oxidation of fatty acids, respectively (Kersten et al. 2000). An up-regulation of these genes by IHE would therefore increase $\beta$-oxidation activity in the liver and would result in a reduction in hepatic triacylglycerol content. Apo CIII and LPL play crucial roles in triacylglycerol metabolism, with early studies having demonstrated that Apo CIII inhibits the hydrolysis of VLDL triacylglycerols by LPL (Sehayek \& Eisenberg, 1991; Aalto-setälä et al. 1992). The decrease in Apo CIII mRNA and the increase in LPL mRNA in the liver of IHE-fed mice may also be responsible for the reduction in hepatic triacylglycerol content and plasma triacylglycerol levels. Administration of IHE was observed to cause a significant reduction in plasma triacylglycerol levels only in Expt 1 (Table 1, A + IHE2 (high) diet). This may be due to the timing of blood collection (blood was taken from non-fasted mice in Expts 2, 3 and 4). Although a significant decrease in hepatic cholesterol content was observed in mice given IHE (Tables 2, 3 and 4), there was no alteration in the hepatic mRNA levels of HMGR and CYP7A1, which are responsible for the synthesis and excretion of cholesterol, respectively. 
Table 4. Body weight, liver weight and hepatic lipid content in mice fed the cholesterol diet, and the cholesterol diets supplemented with isomerized hop extract (IHE) and purified isohumulones for 1 week $\dagger$

(Mean values with standard deviations for seven or eight mice per group)

\begin{tabular}{|c|c|c|c|c|c|c|}
\hline & \multicolumn{2}{|c|}{ C } & \multicolumn{2}{|c|}{$\mathrm{C}+\mathrm{IHE} 2$} & \multicolumn{2}{|c|}{$\mathrm{C}+$ purified isohumulones } \\
\hline & Mean & SD & Mean & SD & Mean & SD \\
\hline Body weight gain (g) & 0.80 & 0.75 & $-0.40^{\star *}$ & 0.70 & $-0.40^{\star \star}$ & 0.73 \\
\hline Final body weight (g) & $17 \cdot 45$ & $1 \cdot 19$ & $16 \cdot 22^{\star}$ & 0.83 & $16 \cdot 50$ & 0.64 \\
\hline Liver weight (g/body kg) & 64.39 & $6 \cdot 38$ & $69 \cdot 71^{*}$ & 4.91 & 67.54 & 2.96 \\
\hline \multicolumn{7}{|l|}{ Liver lipid ( $\mu \mathrm{mol} / \mathrm{g}$ liver) } \\
\hline Cholesterol & $25 \cdot 52$ & $2 \cdot 26$ & $19 \cdot 94^{\star *}$ & $2 \cdot 29$ & $21 \cdot 38^{\star \star}$ & 2.54 \\
\hline
\end{tabular}

$\mathrm{C}$, cholesterol diet group; C + IHE2, C diet supplemented with IHE2 $(10 \mathrm{ml} / \mathrm{kg}$, equivalent to $3 \mathrm{~g}$ isohumulones $/ \mathrm{kg})$ group; $\mathrm{C}+$ purified isohumulones, $\mathrm{C}$ diet supplemented with purified isohumulones $(3 \mathrm{~g} / \mathrm{kg})$ group; $\mathrm{Al}$, atherogenic index; TAG, triacylglycerols.

Mean values were significantly different from those of the $C$ diet group: ${ }^{*} P<0.05,{ }^{* *} P<0.01$.

$\dagger$ For details of diets and procedures, see p. 560 .

Notably, no difference was detected in the content of cholesterol and bile acid in faeces between the control and IHE-fed mice (data not shown).

The genes encoding ACO, ACS, FATP and LPL, whose mRNA were up-regulated by the administration of IHE, are known to be regulated by $\operatorname{PPAR} \alpha$, and our experiments using a transient cotransfection assay in mammalian cells have indicated that isohumulones activate PPAR $\alpha$ at a physiological concentration of $10 \mu \mathrm{m}$ (Yajima et al. 2004). We therefore compared the effects of IHE on lipid metabolism with those of fenofibrate, a well-known PPAR $\alpha$ agonist. It has been shown that agonists of PPAR $\alpha$ induce significant hepatomegaly in mice and accelerate the $\beta$-oxidation of fatty acids in mitochondria, peroxisomes and microsomes in liver (Reddy et al. 1986; Schoonjans et al. 1996a,b; Kersten et al. 2000; Fruchart, 2001). In the present study, we confirmed that the administration of fenofibrate induced hepatomegaly, reduced hepatic cholesterol content, and increased plasma HDL-cholesterol with a concomitant increase in total cholesterol and a decrease in the AI (Table 3). These changes were similar to those observed in mice fed diets containing IHE, although the significant decrease in hepatic

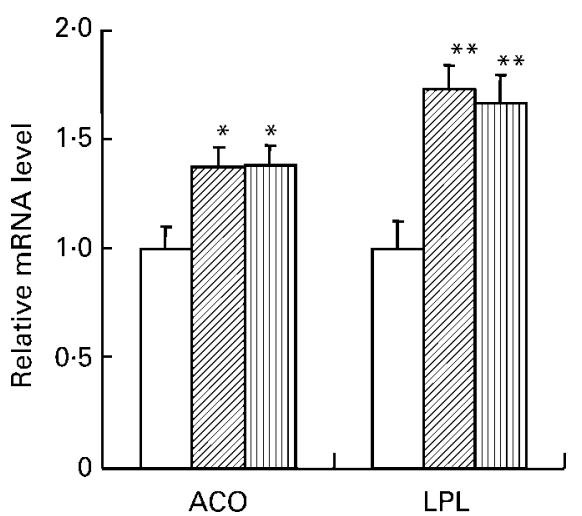

Fig. 4. Quantitative analysis of mRNA in the liver of mice fed the cholesterol diet $(C, \square)$, the cholesterol diet supplemented with isomerized hop extract $(\mathrm{C}+\mathrm{IHE} 2, \mathbb{2})$ and the cholesterol diet supplemented with purified isohumulones $(C+$ purified isohumulones, $\mathbb{d})$ for 1 week. For each gene, the mRNA level is shown relative to its level in the $C$ group (set as 1.0). Values are means with standard deviations represented by vertical bars for six mice per group. Mean values were significantly different from those of the $C$ group: ${ }^{\star} P<0.05 ;{ }^{* \star} P<0.01$. ACO, acyl-CoA oxidase; LPL, lipoprotein lipase. triacylglycerol content was observed only in the IHE-fed mice and the significant increase in plasma HDL-cholesterol was observed only in fenofibrate-fed mice.

Although fenofibrate has been consistently reported to increase HDL-cholesterol levels in humans (Fruchart, 2001), the results from animal studies are controversial. One study has reported that fenofibrate decreased plasma HDL-cholesterol concentration in a rodent model (Berthou et al. 1996). By contrast, fenofibrate has been found to increase HD-cholesterol levels in other rodent models (Oliver et al. 1988; Wang et al. 2001). It has also suggested that dietary fat content may affect lipoprotein metabolism in animals treated with fibrate-like compounds (Guo et al. 2001, Wang et al. 2001). In our experimental conditions, administration of the cholesterol diets containing fenofibrate resulted in the significant increase in plasma HDL-cholesterol (Table 3). Notable increase in HDL-cholesterol by IHE could not be detected in the same condition, although the administration of IHE and the atherogenic diet caused a significant increase in plasma HDL-cholesterol (Table 1). This may be due to the difference in lipid and cholesterol contents between the atherogenic and cholesterol diets.

The decrease in Apo AI mRNA levels observed in mice given IHE was inconsistent with the tendency towards an increase in HDL-cholesterol (Fig. 2 and Table 2). The reason for this discrepancy is unclear. Notably, the level of Apo AI mRNA in the liver of fenofibrate-fed mice was also decreased (data not shown). ACO and LPL mRNA in the liver of fenofibrate-fed mice were up-regulated, as were those in mice fed IHE or isohumulones (Figs. 3 and 4). Taken together, these results suggest that the changes in lipid metabolism observed in the mice given IHE are due, at least in part, to the activation of hepatic PPAR $\alpha$ by isohumulones. Fenofibrate has been reported to reduce the hepatic cholesterol content in rodents (Petit et al. 1988). The decrease in hepatic cholesterol content observed in IHE-fed mice may be caused by a similar mechanism. Recently, fenofibrate was shown to inhibit a high-fat diet-induced body weight gain in C57BL/6 mice (Guerre-Millo et al. 2000), which is compatible with the reduction in body weight observed in mice fed the atherogenic diet with IHE (Table 1).

The present study indicates that IHE i.e. isohumulones and fenofibrate have similar modulatory effects on both plasma and hepatic lipid levels and on the expression of genes involved in lipid metabolism. Our results suggest that activation of the 
nuclear receptor PPAR $\alpha$ in liver by isohumulones is at least partly responsible for the effects observed in the mice given IHE. However, the increases in mRNA levels of PPAR $\alpha$-regulated genes were smaller in the mice given IHE than in those given fenofibrate, although a significant effect on the hepatic lipid content was observed in both groups (Fig. 3). It should be noted that the administration of a low amount of IHE with the cholesterol diet (equivalent to $0.9 \mathrm{~g}$ isohumulones $/ \mathrm{kg}$ cholesterol diet) significantly decreased hepatic cholesterol and triacylglycerol content in mice, without causing a notable increase in ACO and LPL mRNA (data not shown). This result may suggest that the modulatory effects of isohumulones on lipid metabolism are only partially mediated by PPAR $\alpha$. The amounts of isohumulones taken by the animals fed the diet containing isohumulones at $3 \mathrm{~g} / \mathrm{kg}$ diet, the most effective concentration, was approximately $500 \mathrm{mg} / \mathrm{kg}$ body weight $(10 \mathrm{mg}$ per animal). Therefore, the amount of beer could be roughly calculated to be $5-501 / \mathrm{kg}$ body weight per d, since the concentration of isohumulones in beer varies between 10 and $100 \mathrm{mg} / \mathrm{l}$. It is not realistic to take sufficient amounts of isohumulones through beer to expect the modulatory effect on lipid metabolism. On the basis of our current findings, it is likely that the compounds responsible for beer bitterness, isohumulones, function to normalize lipid metabolism. Further studies are necessary to verify how isohumulones affect lipid metabolism and to assess their potential application as therapeutic agents.

\section{Acknowledgements}

We are grateful to Professor T. Miyazawa of Tohoku University (Sendai, Japan) and Professor H. Yokogoshi of University of Shizuoka (Shizuoka, Japan) for valuable discussions.

\section{References}

Aalto-Setälä K, Fisher EA, Chen X, Chajek-Shaul T, Hayek T, Zechner R, Walsh A, Ramakrishnan R, Ginsberg HN \& Breslow JL (1992) Mechanism of hypertriglyceridemia in human apolipoprotein (Apo) CIII transgenic mice. Diminished very low density lipoprotein fraction catabolic rate associated with increased Apo CIII and reduced Apo E on the particles. J Clin Invest 90, 1889-1900.

American Institute of Nutrition (1977) Report of the American Institute of Nutrition ad hoc writing committee on standard diets for nutritional studies. J Nutr 107, 1340-1348.

Berthou L, Duverger N, Emmanuel F, et al. (1996) Opposite regulation of human versus mouse apolipoprotein A-1 by fibrates in human apolipoprotein A-1 transgenic mice. J Clin Invest 97, 2408-2416.

Brenner H, Rothenbacher D, Bode G, März W, Hoffmeister A \& Koenig W (2001) Coronary heart disease risk reduction in a predominantly beer-drinking population. Epidemiology 12, 390-395.

Carr TP, Andresen CJ \& Rudel LL (1993) Enzymatic determination of triglyderide, free cholesterol, and total cholesterol in tissue lipid extracts. Clin Biochem 26, 39-42.

Cripui MH \& Ringel BL (1994) Does diet or alcohol explain the French paradox? Lancet 344, 1719-1723.

Doll R, Peto R, Hall E, Wheatley K \& Gray R (1994) Mortality in relation to consumption of alcohol: 13 years' observations on male British doctors. Br Med J 309, 911-918.

Fruchart JC (2001) Peroxisome proliferator-activated receptor- $\alpha$ activation and high-density lipoprotein metabolism. Am J Cardiol 88, $24 \mathrm{~N}-29 \mathrm{~N}$.
Fuchs CS, Stampfer MJ, Colditz GA, Giovannucci EL, Manson JE \& Kawachi I (1995) Alcohol consumption and mortality among women. $N$ Engl J Med 322, 1245-1250.

Gaziano JM, Gaziano TA \& Glynn RJ (2000) Light-to-moderate alcohol consumption and mortality in the Physicians' Health Study. J Am Coll Cardiol 35, 96-105.

Guerre-Millo M, Gervois P, Raspé E, et al. (2000) Peroxisome proliferator-activated receptor $\alpha$ activators improve insulin sensitivity and reduce adiposity. J Biol Chem 275, 16638-16642.

Guo Q, Wang PR, Milot DP, Ippolito MC, Hernandez M, Burton CA, Wright SD \& Chao Y (2001) Regulation of lipid metabolism and gene expression by fenofibrate in hamsters. Biochim Biophys Acta 1533, 220-232.

Ha YC \& Barter PJ (1985) Rapid separation of plasma lipoprotein by gel permeation chromatography on agarose gel Superose 6B. J Chromatogr 341, 154-159.

Hayek T, Fuhrman B, Vaya J, Rosenblat M, Belinky P, Coleman R, Elis A \& Aviram M (1997) Reduced progression of atherosclerosis in apolipoprotein E-deficient mice following consumption of red wine, or its polyphenols quercetin or catechin, is associated with reduced susceptibility of LDL to oxidation and aggregation. Atherioscler Thromb Vasc Biol 17, 2744-2752.

Hoffmeister H, Schelp FP, Mensink GB, Dietz E \& Bohning DR (1999) The relationship between alcohol consumption, health indicators and mortality in the German population. Int $J$ Epidemiol 28, 1066-1072.

Honma Y, Tobe H, Makishima M, Yokoyama A \& Okabe-Kado J (1998) Induction of differentiation of myelogenous leukemia cells by humulone, a bitter in the hop. Leuk Res 22, 605-610.

Kersten S, Desvergne B \& Wahll W (2000) Roles of PPARs in health and disease. Nature 405, 421-424.

Mayer O, Simon J \& Rosolova H (2001) A population study of the influence of beer consumption on folate and homocysteine concentrations. Eur J Clin Nutr 55, 605-609.

Mennen LI, de Courcy GP, Guilland JC, Ducros V, Zarebska M, Bertrais S, Favier A, Hercberg S \& Galan P (2003) Relation between homocysteine concentrations and the consumption of different types of alcoholic beverages: the French Supplementation with Antioxidant Vitamins and Minerals Study. Am J Clin Nutr 78, 334-338.

Miranda CL, Stevens JF, Helmrich A, Henderson MC \& Rodriguez RJ (1993) Commonly occurring plant flavonoids have estrogenic activity. Mol Pharmacol 44, 37-43.

Mizobuchi S \& Sato Y (1984) A new flavanone with antifungal activity isolated from hops. Agric Biol Chem 48, 2771-2275.

Mizobuchi S \& Sato Y (1985) Antifungal activity of hop bitter resins and related compounds. Agric Biol Chem 49, 399-403.

Nigdikar SV, Williams NR, Griffin BA \& Howard AN (1998) Consumption of red wine polyphenols reduces the susceptibility of LDL to oxidation in vivo. Am J Clin Nutr 68, 258-265.

Nishina PM, Verstuyft J \& Painen B (1990) Synthetic low and high fat diets for the study of atherosclerosis in the mouse. J Lipid Res 31, 859-869.

Nishina PM, Wang J, Toyofuku W, Kuypers FA, Ishida BY \& Painen B (1993) Atherosclerosis and plasma and liver lipids in nine inbred strains of mice. Lipids 28, 599-605.

Oliver P, Plancke MO, Marzin D, Clavey V, Sauzieres J \& Fruchart JC (1988) Effects of fenofibrate, gemfibrozil and nicotinic acid on plasma lipoprotein levels in normal and hyperlipidemic mice. Atherosclerosis 70, 107-114.

Petit D, Bonnefis MT \& Infante R (1988) Effects of ciprofibrate and fenofibrate on liver lipids and lipoprotein synthesis in normo- and hyperlipidemic rats. Atherosclerosis 74, 2215-2241.

Reddy JK, Goel SK, Nemali MR, Carrino JJ, Laffler TG, Reddy MK, Sperbeck SJ, Osumi T, Hashimoto T \& Lalwani ND (1986) Transcription regulation of peroxisomal fatty acyl-CoA oxidese and enoyl-CoA hydratase/3-hydroxyacyl-CoA dehydrogenase in rat liver by peroxisome proliferators. Proc Natl Acad Sci USA 83, $1747-1751$. 
Reeves PG, Nielsen FH \& Fahey GC (1993) AIN-93 purified diets for laboratory rodents: final report of the American Institute of Nutrition ad hoc writing on the reformation of the AIN-76 rodent diet. J Nutr 123, 1939-1951.

Renaud S \& de Lorgeril M (1992) Wine, alcohol, platelets, and the French paradox for coronary heart disease. Lancet 339, 1523-1526.

Schoonjans K, Staels B \& Auwerx J (1996a) Role of the peroxisome proliferator-activated receptors (PPAR) in mediating the effects of fibrates and fatty acids on gene expression. J Lipid Res 37, 907-925.

Schoonjans K, Staels B \& Auwerx J (1996b) The peroxisome proliferatoractivated receptor (PPAR) and their effects on lipid metabolism and adipocyte differentiation. Biochim Biophys Acta 1302, 92-109.

Sehayek E \& Eisenberg S (1991) Mechanisms of inhibition by apolipoprotein $\mathrm{C}$ of apolipoprotein E-dependent cellular metabolism of human triglyceride-rich lipoproteins through the low density lipoprotein receptor pathway. J Biol Chem 270, 18259-18267.

Shimamura M, Hazato T, Ashino H, Yamamoto Y, Iwasaki E, Tobe H, Yamamoto K \& Yamamoto S (2001) Inhibition of angiogenesis by humulone, a bitter acid from beer hop. Biochem Biophys Res Commun 289, 220-224.

Suh I, Shaten BJ, Culter JA \& Kuller LH (1992) Alcohol use and mortality from coronary artery disease: the role of high-density lipoprotein cholesterol. The Multiple Risk Factor Intervention Trial Research Group. Ann Intern Med 116, 881-887.
Tobe H, Kubota M, Yamaguchi M, Kocha T \& Aoyagi T (1997a) Apoptosis to HL-60 by humulone. Biosci Biotechnol Biochem 61 , 1027-1029.

Tobe H, Muraki Y, Kitamura K, Komiyama O, Sato Y, Sugioka T, Maruyama HB, Matsuda E \& Nagai M (1997b) Bone resorption inhibitors from hop extract. Biosci Biotechnol Biochem 61, 158-159.

Van der Gaag MS, Ubbink JB, Sillanaukee P, Nikkari S \& Hendriks HF (2000) Effect of consumption of red wine, spirits, and beer on serum homocysteine. Lancet 355, 1522.

Wang PR, Guo Q, Ippolito M, Wu M, Milot D, Ventre J, Doebber T, Wright SD \& Chao YS (2001) High fat fed hamster, a unique animal model for treatment of diabetic dyslipidemia with peroxisome proliferator activated receptor $\alpha$ selective agonist. Eur J Pharmacol 427, 285-293.

Yajima H, Ikeshima E, Shiraki M, Kanaya T, Fujiwara D, Odai H, Tsuboyama-Kasaoka N, Ezaki O, Oikawa S \& Kondo K (2004) Isohumulones, bitter acids derived from hops, activate both peroxisome proliferators-activated receptor $\alpha$ and $\gamma$ and reduce insulin resistance. $J$ Biol Chem 279, 33456-33462.

Yamamoto K, Wang J, Yamamoto S \& Tobe H (2000) Suppression of cyclooxygenase-2 gene transcription by humulon of beer hop extract studied with reference to glucocorticoid. FEBS Lett 465, 103-106.

Yasukawa K, Takeuchi M \& Takido M (1995) Humulon, a bitter in the hop, inhibits tumor promotion by $12-O$-tetradecanoylphorbol-13-acetate in two-stage carcinogenesis in mouse skin. Oncology 52, 156-158. 